\title{
The effects of physical exercise, caloric diet restriction and antioxidant supplementation on the aging process in rats
}

\author{
Sobhi A Al Kafafi, Samy H Hammady*, Mohamed I El-Noueam, Eman \\ M Fawzy, Eman A Shaat**, Gihan Y Shoeib \\ Physiology, Pharmacology \& Drug Toxicology*, \\ Medical Biochemistry** Departments. \\ Faculty of Medicine, Alexandria University, Egypt
}

\begin{abstract}
The objective of the present study was to assess the effects of age, physical exercise, caloric diet restriction (CR), and vitamin E supplementation on some markers of oxidative stress, DNA damage, apoptosis and liver function in different age groups of rats. The present study included 120 male "Wistar rats", divided into 3 age groups; 12, 18 and 24 months old. Each group was further subdivided into 4 subgroups; 10 rats each. The first subgroup as a control, the second underwent exercise training, the third was kept on CR and the last was supplemented with vitamin E. The measured biochemical parameters included; serum malondialdehyde (MDA), as well as \% DNA fragmentation levels, the active caspase-3 concentration and the monoamine oxidase$\beta$ (MAO- $\beta$ ) enzyme activity in the brain of all studied rats. In addition, hepatic superoxide dismutase (SOD) and NADPH-cytochrome c reductase enzyme activities were assessed. The results of this study showed that; the aging process was associated with significantly increased serum MDA, decreased hepatic SOD activity, increased brain DNA fragmentation and caspase-3 activation as well as decreased cytochrome $c$ reductase activity of liver. However, exercise, $C R$, and vitamin $E$ supplementation caused a significant decrease in serum MDA and increase in hepatic cytochrome c reductase activity in old group. In addition, exercise could increase $S O D$ and lower caspase-3 in old rats, while CR had no significant effect on both of them. Neither age nor any of the used intervention trials had an effect on brain MAO$\beta$ activity. It is suggested that the age-induced oxidative stress, DNA damage and improper hepatic metabolism could be partially attenuated by exercise, $C R$, and/or vitamin E supplementation. All these beneficial effects might be mostly effective in older age.

Keywords: Aging, oxidants, antioxidant, physical exercise, caloric diet restriction, vitamin E, lipid peroxidation, apoptosis, monoamine oxidase- $\beta$, caspase-3, DNA fragmentation, cytochrome c reductase.

Abbreviations: ROS; reactive oxygen species, DNA; deoxyribonucleic acid, $m t-D N A$; mitochondrial DNA, CR; caloric diet restriction, MDA; malondialdehyde, SOD; superoxide dismutase, $M A O-\beta$; monoamine oxidase- $\beta, N A D P^{+}$; nicotinamide adenine dinucleotide phosphate.
\end{abstract}




\section{INTRODUCTION}

The study of aging has expanded very rapidly in the recent decades. This might be due to the worldwide, extraordinary increasing percentage of elderly, and the subsequent increased proportion of the national health expenditures utilized by them. ${ }^{(1)}$

Aging is an inevitable physiological process characterized by loss of functions and loss of resistance to various types of stress. It is a multifactorial \& complex process. ${ }^{(2)}$ Many attempts have been done to understand its causes and mechanisms, but still all are theories.

Theories of aging have been grouped into several categories, and the free radical theory of aging is one of the best theories that can explain the process, up-till now. The overproduction of oxidants and their subsequent cumulative damage may with time-exceed the protecting potential of the cells, which ultimately leads to a decline in the physiological capacity of the whole organism and induces oxidative stress. ${ }^{(3)}$

Oxidative stress may activate mitochondria-mediated apoptotic pathways, since mitochondria of aged neurons produce more oxidants, accumulate calcium, and exhibit increased oxidative damage, all known stimuli for apoptosis. ${ }^{(4)}$

Actually, the accumulation of the oxidatively damaged and mutated mitochondrial DNA (mt-DNA) molecules, together with the enhanced apoptosis, may act synergistically to cause the general decline in biochemical and physiological functions of body cells, which are characteristics of aging. ${ }^{(5)}$
Apoptosis is an active, rapid, gene-regulated physiological cell death with characteristic features. It starts early in the intrauterine life and continues along life. ${ }^{(6)}$ Apoptosis is characterized by the activation of a specific family of proteases called "the caspases". Caspase- 3 is one of the most active members of this family. It can affect the activity of several cellular enzymes that are responsible for apoptosis. ${ }^{(7)}$

Monoamine oxidase- $\beta$ (MAO- $\beta$ ) catalyses the metabolism of brain dopamine with production of a high level of hydrogen peroxide, a major oxidant that causes damage to mtDNA. $^{(8)}$

The aim of the present study was to evaluate the effect of aging process on oxidant (MDA), some antioxidant liver enzymes (SOD), DNA damage (\% DNA fragmentation) and apoptosis markers (active caspase-3) in brain as well as on hepatic drug metabolizing enzyme (NADPH-cytochrome c reductase). In addition, it aimed to assess the role of physical exercise, caloric diet restriction (CR) and vitamin $\mathrm{E}$ supplementation on these parameters in different age groups.

\section{MATERIAL \& METHODS}

\section{Animal model:}

The study was carried out on 120 male "Wistar rats", divided into 3 main groups; according to their age:

Group I: 40 young adult rats (12 months old).

Group II: 40 adult rats (18 months old).

Group III: 40 old rats (24months old). 
Each of the main age groups was further subdivided into 4 subgroups; 10 rats each:

Subgroup (1): The control subgroup; which was kept on balanced diet, with food ad libitum.

Subgroup (2): This subgroup underwent exercise training by swimming. ${ }^{(9)}$

Subgroup (3): The rats were kept on caloric diet restriction by $30 \%$ from ad libitum intake. ${ }^{(\mathbf{1 0})}$

Subgroup (4): This subgroup was supplemented with exogenous vitamin $\mathrm{E}$ (5000 IU/kg diet). ${ }^{(11)}$

\section{Biochemical analysis:}

At the end of the 6 months of the experiment, all rats were killed in the fed state and at the same time in the morning. Rats were subjected to light ether anaesthesia, and blood samples were collected from the retro-orbital venous plexus and serum was separated and stored at $-20^{\circ} \mathrm{C}$.Then, rats were sacrificed by decapitation.

Brain dissection: Brains were rapidly removed from the skull, washed with cold saline and immediately frozen on dry ice. Each brain was divided into 2 parts. The $1^{\text {st }}$ part was stored at $-70^{\circ} \mathrm{C}$ to estimate MAO- $\beta$ activity. The 2 nd part of the brain was used to prepare cell culture.

Cell culture: The $2^{\text {nd }}$ brain part from each rat was dissected into 1-2 mm pieces then suspended in 2 tubes, each containing RPMI 1640 medium and supplemented with $2 \mathrm{mM}$ Lglutamine, sodium bicarbonate $\left(\mathrm{NaHCO}_{3}\right), 100 \mathrm{U} / \mathrm{ml}$ penicillin, 100 $\mu \mathrm{g} / \mathrm{ml}$ streptomycin, $1 \%$ bovine serum albumin, and $30 \mu \mathrm{M}$ glutamate, as an inducer of apoptosis. ${ }^{(12)}$ The cells were cultured for 15 hours at $37^{\circ} \mathrm{C}$. The cultured cells were used to determine the \% DNA fragmentation $\&$ active caspase -3 concentration.

Liver dissection: The abdomen was then opened, the liver was isolated, divided into 2 parts and stored at $70^{\circ} \mathrm{C}$. The first part was used for preparation of microsomes by homogenization in $0.25 \mathrm{M}$ sucrose then successive centrifugation to obtain microsomal pellet which was resuspended in $1.15 \% \mathrm{KCl}$. The second part was used to prepare crude homogenate in phosphate buffered saline (pH 7.4). By centrifugation, the supernatant was saved.

Malondialdehyde (MDA): Serum MDA concentration was estimated by thiobarbituric acid reaction, ${ }^{(13)}$ using $1,1,3,3$ tetramethoxypropane as a standard. They were expressed as $\mathrm{nM} / \mathrm{ml}$.

DNA fragmentation assay: DNA fragmentation in cultured induced brain cells was quantitated by diphenylamine(DPA) method. ${ }^{(\mathbf{1 4 , 1 5})}$ The cells were harvested by centrifugation, washed by PBS and the pellet was lysed with lysis buffer $(0.5 \%$ triton $\mathrm{X}-100,10 \mathrm{mM}$ tris- $\mathrm{HCl}$ $\mathrm{pH} 7.5,2 \mathrm{mM}$ EDTA) for $20 \mathrm{~min}$. on ice. The lysate was centrifuged at $13,000 \mathrm{xg}$ for $20 \mathrm{~min}$. to separate intact from fragmented chromatin. Both pellets and supernatants were precipitated overnight at $4^{\circ} \mathrm{C}$ in $12.5 \%$ trichloroacetic acid (TCA) .The precipitate was sedimented at 13,000 $\mathrm{x} \mathrm{g}$, resuspended in 5\% TCA and heated at $90^{\circ} \mathrm{C}$ for $10 \mathrm{~min}$. Then DPA reagent $(0.15 \mathrm{~g}$ DPA, $0.15 \mathrm{ml}$ sulfuric acid, $0.05 \mathrm{ml}$ acetaldehyde $(16 \mathrm{mg} / \mathrm{ml}$ stock) $/ 10 \mathrm{ml}$ glacial acetic acid was added to each tube. After overnight incubation the optical densities at $570 \mathrm{~nm}$ were read. The \% DNA 
fragmentation was calculated as the ratio of DNA in the $13,000 \times \mathrm{xg}$ supernatant to the total DNA recovered in the $13,000 \mathrm{xg}$ supernatant and pellet.

Caspase-3 determination: ${ }^{(16)}$ The active caspase- 3 concentration in brain cell extracts was estimated by sandwich ELISA technique (Quantikine, R\&D Systems, USA). After induction of apoptosis, BiotinZKVD-fmk was added to culture media and incubated for an hour. This biotinylated caspase inhibitor was used to covalently modify the large subunit of caspase-3 (apocaspase-3), as it enters apoptotic cells and form a stable thio-ether bond with the cysteine on the active site. The active caspas-3 assay was performed according to manufacturer' instructions. The sesitivity of that test was less than $0.1 \mathrm{ng} / \mathrm{ml}$ and no crossreactivity with active caspase-2,-7,$8, \&-9$. The coefficient of variation $\%$ of intra-assay and inter-assay ranged from 2.6-5.2\% and 5.8-6.6\% respectively. The active caspase- 3 concentrations were expressed as $\mathrm{ng} / \mathrm{mg}$ protein. Protein concentration in different samples was estimated by Lowry method. ${ }^{(17)}$ using bovine serum albumin as a standard.

Monoamine oxidase- $\beta$ (MAO- $\beta$ ) activity:(18) The activity of MAO- $\beta$ was determined using a modified 3(4,5-dimethylthiazol-2-yl)-2,5-

diphenyltetrazolium bromide (MTT) reduction assay. Members of the respiratory chain reduce the MTT dye, and this reduction is inhibited by increased activity of MAO- $\beta$ and the subsequent increase of $\mathrm{H}_{2} \mathrm{O}_{2}$. Here MTT reduction using succinate was used as an indirect reciprocal index of
MAO- $\beta$ activity. Breifly, the stored brain portion was homogenised in MSH solution(70mM mannitol, 230mM sucrose, $5 \mathrm{mM}$ HEPES buffer; $\mathrm{pH} 7.5$ ), then centrifuged at $600 \times \mathrm{xg}$ for 10 min. The supernatant was centrifuged again at $15,000 \times \mathrm{xg}$ for 10 min. to obtain the mitochndrial pellet. This pellet was resuspended in isolation buffer (5mM morphinobutane-sulfonate, $225 \mathrm{mM}$ mannitol, $75 \mathrm{mM}$ sucrose, $1 \mathrm{mM}$ ethylene-glycoltetraacetic acid; $\mathrm{pH} 7.4)$. Two sets of mitochodrial suspension ( $2 \mathrm{mg}$ protein $/ \mathrm{ml}$ ) were prepared and MAO substrate (benzylamine; 500uM final concentration) was added to the first set and distilled water to the second one (as a control sample). After 1 hour incubation at $37^{\circ} \mathrm{C}$ a mixture of MTT $(0.42 \mathrm{mg} / \mathrm{ml})$ and succinate (15mM)was added. Samples were quenched with lysis buffer $(10 \%$ SDS and $\quad 45 \% \quad$ dimethylformamide; adjusted to $\mathrm{pH} 4.7$ with glacial acetic acid). After 5 min., absorbance were taken as the difference between 550 and $620 \mathrm{~nm}$. Results were expressed as a $\%$ of the corresponding control value.

Superoxide dismutase (SOD) activity: It was assayed in crude liver homogenate by the pyrogallol method $^{(\mathbf{1 9})}$ SOD activity was caculated from the standard curve, and then expressed as $\mathrm{U} / \mathrm{mg}$ protein.

NADPH-cytochrome $c$ reductase activity: ${ }^{(20)}$ The reaction mixture consisted of $0.05 \mathrm{M}$ potassium phosphate buffer ( $\mathrm{pH} 7.5$ ) containing $0.1 \mathrm{mM}$ EDTA, $15 \mathrm{mM}$ potassium cyanide, microsomal liver suspension and cytochrome $\mathrm{c}(4 \mathrm{mM})$. The reaction was initiated by addition of NADPH $(10 \mathrm{mM})$.The contents were mixed 
and the reaction was followed for 4 min. at $550 \mathrm{~nm}$ on spectrophotometer. The enzyme activity was expressed as $\mathrm{nM} / \mathrm{min}$./mg microsomal protein using an extinction coefficient of $21 \mathrm{mM}^{-}$ ${ }^{1} \mathrm{~cm}^{-1}$.

Statistical analysis: SPSS 8.0 software (SPSS Inc., Chicago, IL) was used for statistical analysis and $\mathrm{p}<$ 0.05 was considered statistically significant. Results were expressed as means \pm standard deviation (mean $\pm \mathrm{SD})$. One-way ANOVA (F) test was done to compare between different groups. To study the effect of age on different parameters, adult and old groups were compared verus young one. To evaluate the effect of different intervention trials, the results of each were compared with their corresponding age non- intervened group.

\section{RESULTS}

Serum MDA and hepatic SOD levels: (Table I, II)

As compared to young control group, serum MDA significantly increased in adult group, while SOD significantly decreased in adult and old groups with age.

Exercise had no effect on MDA in young group but significantly decreased SOD. In adult group, exercise decreased MDA with no significant effect on SOD. However, in old exercised group, significantly lower MDA and higher SOD level were observed.

C R significantly increased MDA in young rats while significantly decreased it in adult ones. CR had no effect on SOD in all age groups.

Vitamin E significantly decreased MDA in adult and old groups and decreased SOD in young and old groups.

\%DNA fragmentation and active caspase-3 levels: (Table III, IV)

In control group, \%DNA fragmentation significantly increased in adult rats and together with increased active caspase-3 levels in old ones.

Swimming significantly increased $\%$ DNA fragmentation and active caspase-3 levels in young group without any significant effect on them in adult ones. In old group, exercise decreased active caspase-3 levels significantly.

C $R$ significantly increased $\%$ DNA fragmentation in young rats, while decreased it in old ones. CR had no effect on caspase-3 levels.

Vitamin E supplementation was associated with higher \%DNA fragmentation in adult group. Old group showed lower \%DNA fragmentation and higher caspase-3 levels.

MAO- $\beta$ activity: (Table V)

Non-significant change in MAO$\beta$ activity was observed between different age groups. Non of the used intervention trials had an effect on its activity.

NADPH-cytochrome c reductase activity: (Table VI)

NADPH-cytochrome c reductase activity significantly decreased with age in control group. Exercise, CR and vitamin $\mathrm{E}$ significantly decreased its activity in young group and increased it in old one. 
Table I: Serum malondialdehyde (MDA) level in $\mathrm{nM} / \mathrm{ml}$ of the different studied groups:

\begin{tabular}{|c|c|l|l|l|l|}
\hline \multicolumn{2}{|l|}{$\begin{array}{l}\text { Serum MDA } \\
(\mathrm{nM} / \mathrm{ml})\end{array}$} & \multicolumn{4}{|c|}{ Subgroups } \\
\cline { 3 - 6 } \multicolumn{2}{|c|}{} & $\begin{array}{c}1 \\
\mathrm{n}=10\end{array}$ & $\begin{array}{c}2 \\
\mathrm{n}=10\end{array}$ & $\begin{array}{c}3 \\
\mathrm{n}=10\end{array}$ & $\begin{array}{c}4 \\
\mathrm{n}=10\end{array}$ \\
\hline I & Mean & 1.92 & 1.43 & $2.72^{\mathbf{a}} *$ & 2.05 \\
12 month & \pm SD & 0.93 & 0.55 & 0.69 & 0.36 \\
\hline II & Mean & $2.52^{\mathbf{b}_{*}}$ & $1.23^{\mathbf{a}^{* * *}}$ & $1.71^{\mathbf{a}^{*}}$ & $1.51^{\mathbf{a}^{* *}}$ \\
18 month & \pm SD & 0.79 & $0.49^{\mathbf{a}^{* *}}$ & 1.15 & 0.60 \\
\hline III & Mean & 1.39 & $0.69^{\mathbf{a}^{* *}}$ & 0.99 & $0.8^{\mathbf{a}^{* *}}$ \\
24 month & \pm SD & 0.88 & 0.29 & 0.32 & 0.34 \\
\hline
\end{tabular}

1: control 2: swimming 3: diet restricted 4: vitamin E supplemented a: significance versus subgroup 1 of same age.

b: significance versus group I (12 month )(only for subgroup 1)

$*: \mathrm{p}<0.05 * *: \mathrm{p}<0.01 * * *: \mathrm{p}<0.001$

Table II: Superoxide dismutase (SOD) activity of the liver in U/mg protein of the different studied groups:

\begin{tabular}{|c|c|c|c|c|c|}
\hline \multirow{2}{*}{\multicolumn{2}{|c|}{$\begin{array}{l}\text { SOD activity } \\
\text { (U/ mg protein) }\end{array}$}} & \multicolumn{4}{|c|}{ Subgroups } \\
\hline & & 1 & 2 & 3 & 4 \\
\hline $\begin{array}{c}\mathrm{I} \\
12 \text { month }\end{array}$ & $\begin{array}{l}\text { Mean } \\
\pm \mathrm{SD}\end{array}$ & $\begin{array}{l}23.94 \\
2.50\end{array}$ & $\begin{array}{l}16.20^{\mathbf{a}^{* k \ldots k}} \\
2.18\end{array}$ & $\begin{array}{l}21.75 \\
6.50\end{array}$ & $\begin{array}{l}16.41^{a^{2 k * k}} \\
068\end{array}$ \\
\hline $\begin{array}{c}\text { II } \\
18 \text { month }\end{array}$ & $\begin{array}{l}\text { Mean } \\
\pm \text { SD }\end{array}$ & $\begin{array}{l}17.92^{b^{* * *}} \\
1.70\end{array}$ & $\begin{array}{l}14.87 \\
1.19\end{array}$ & $\begin{array}{l}15.02 \\
3.39\end{array}$ & $\begin{array}{l}14.43 \\
3.23\end{array}$ \\
\hline $\begin{array}{c}\text { III } \\
24 \text { month }\end{array}$ & $\begin{array}{l}\text { Mean } \\
\pm \text { SD }\end{array}$ & $\begin{array}{l}21.39^{\mathbf{b}^{*}} \\
2.57\end{array}$ & $\begin{array}{l}25.43^{\mathrm{a}^{* * *}} \\
2.20\end{array}$ & $\begin{array}{l}18.64 \\
2.51\end{array}$ & $\begin{array}{l}17.53^{\mathbf{a}^{k * k}} \\
2.97\end{array}$ \\
\hline
\end{tabular}

1: control 2: swimming 3: diet restricted 4: vitamin E supplemented a: significance versus subgroup 1 of same age.

b: significance versus group I (12 month )(only for subgroup 1)

$*: \mathrm{p}<0.05 * *: \mathrm{p}<0.01 * * *: \mathrm{p}<0.001$ 
Table III: \%DNA fragmentation of the brain of the different studied groups:

\begin{tabular}{|c|c|l|l|l|l|}
\hline \multicolumn{2}{|l|}{$\begin{array}{l}\text { \%DNA } \\
\text { fragmentation }\end{array}$} & \multicolumn{4}{|c|}{ Subgroups } \\
\cline { 3 - 6 } \multicolumn{2}{|c|}{} & $\begin{array}{c}1 \\
\mathrm{n}=10\end{array}$ & $\begin{array}{c}2 \\
\mathrm{n}=10\end{array}$ & $\begin{array}{c}3 \\
\mathrm{n}=10\end{array}$ & $\begin{array}{c}4 \\
\mathrm{n}=10\end{array}$ \\
\hline \multirow{2}{*}{ I } & Mean & 24.4 & $53.3^{\mathbf{a}^{* * * *}}$ & $42.35^{\mathbf{a}^{* * * *}}$ & 29.6 \\
12 month & \pm SD & 8.13 & 16.08 & 6.49 & 10.14 \\
\hline II & Mean & $37.2^{\mathbf{b}^{*}}$ & 29.62 & 31.95 & $48.26^{\mathbf{a}^{*}}$ \\
18 month & \pm SD & 13.28 & 7.12 & 9.58 & $11.45^{\mathbf{a}^{*}}$ \\
\hline III & Mean & $44.6^{\mathbf{b}^{* * *}}$ & 43.03 & $36.05^{\mathbf{a}^{*}}$ & $36.35^{\mathbf{a}^{*}}$ \\
24 month & \pm SD & 9.86 & 6.44 & 7.96 & 7.944 \\
\hline
\end{tabular}

1: control 2: swimming 3: diet restricted 4: vitamin E supplemented a: significance versus subgroup 1 of same age.

b: significance versus group I (12 month )(only for subgroup 1)

$*: \mathrm{p}<0.05 * *: \mathrm{p}<0.01 * * *: \mathrm{p}<0.001$

Table IV: Active Caspase-3 enzyme of the brain in $\mathrm{ng} / \mathrm{mg}$ protein of the different studied groups:

\begin{tabular}{|c|c|c|c|c|c|}
\hline \multirow{2}{*}{\multicolumn{2}{|c|}{$\begin{array}{l}\text { Caspase- } 3 \text { activity } \\
\text { (ng/mg protein) }\end{array}$}} & \multicolumn{4}{|c|}{ Subgroups } \\
\hline & & \multirow{2}{*}{$\begin{array}{c}1 \\
n=10 \\
0.67\end{array}$} & \multirow{2}{*}{$\begin{array}{c}2 \\
\mathrm{n}=10\end{array}$} & \multirow{2}{*}{$\begin{array}{c}3 \\
n=10 \\
0.69\end{array}$} & \multirow{2}{*}{$\begin{array}{c}4 \\
n=10\end{array}$} \\
\hline $\mathrm{I}$ & Mean & & & & \\
\hline 12 months & $\pm \mathrm{SD}$ & 0.17 & 0.29 & 0.24 & 0.26 \\
\hline II & Mean & 0.79 & 0.67 & 0.67 & 1.00 \\
\hline 18 months & $\pm \mathrm{SD}$ & 0.29 & 0.23 & 0.24 & 0.29 \\
\hline III & Mean & $1.33^{\mathbf{b}^{* * * k}}$ & $0.89^{\mathbf{a}^{*}}$ & 1.20 & $1.73^{\mathrm{a}^{*}}$ \\
\hline 24 months & $\pm \mathrm{SD}$ & 0.45 & 0.17 & 0.25 & 0.72 \\
\hline
\end{tabular}

1: control 2: swimming 3: diet restricted 4: vitamin E supplemented a: significance versus subgroup 1 of same age.

b: significance versus group I (12 month )(only for subgroup 1)

$*: \mathrm{p}<0.05^{* *}: \mathrm{p}<0.01 * * *: \mathrm{p}<0.001$ 
Table V: Monoamine oxidase- $\beta$ (MAO- $\beta$ ) enzyme activity of the brain in \% of MTT reduction of the different studied groups:

\begin{tabular}{|c|c|l|l|l|l|}
\hline \multirow{2}{*}{ \% MTT reduction } & \multicolumn{4}{|c|}{ Subgroups } \\
\cline { 3 - 6 } \multicolumn{2}{|c|}{} & \multicolumn{1}{|c|}{$\begin{array}{c}2 \\
\mathrm{n}=10\end{array}$} & $\begin{array}{c}3 \\
\mathrm{n}=10\end{array}$ & \multicolumn{1}{c|}{$\begin{array}{c}\mathrm{n}=10 \\
\mathrm{n}=10\end{array}$} \\
\hline I & Mean & 44.67 & 40.17 & 30.84 & 20.07 \\
12 months & \pm SD & 20.95 & 8.04 & 6.31 & 7.33 \\
\hline II & Mean & 35.13 & 33.18 & 31.52 & 38.29 \\
18 months & \pm SD & 5.58 & 8.21 & 10.31 & 7.27 \\
\hline III & Mean & 48.55 & 55.22 & 38.35 & 40.77 \\
24 months & \pm SD & 22.99 & 11.81 & 14.09 & 18.27 \\
\hline
\end{tabular}

1: control 2: swimming 3: diet restricted 4: vitamin E supplemented a: significance versus subgroup 1 of same age.

b: significance versus group I (12 month )(only for subgroup 1)

Table VI: NADPH cytochrome c reductase enzyme activity of the liver in $\mathrm{nM}$ / $\mathrm{min} / \mathrm{mg}$ protein of the different studied groups:

\begin{tabular}{|c|c|c|c|c|c|}
\hline \multirow{2}{*}{\multicolumn{2}{|c|}{$\begin{array}{l}\text { cytochrome c reductase } \\
\mathrm{nM} / \mathrm{min} / \mathrm{mg} \text { protein }\end{array}$}} & \multicolumn{4}{|c|}{ Subgroups } \\
\hline & & 1 & 2 & 3 & 4 \\
\hline $\begin{array}{c}\text { I } \\
12 \text { months }\end{array}$ & $\begin{array}{r}\text { Mean } \\
\pm \mathrm{SD}\end{array}$ & $\begin{array}{l}44.09 \\
16.12 \\
\end{array}$ & $\begin{array}{l}33.20^{\mathrm{a}^{*}} \\
7.916\end{array}$ & $\begin{array}{l}11.81^{\mathrm{a}^{* * * k}} \\
2.35\end{array}$ & $\begin{array}{l}20.14^{\mathrm{a}^{* * *}} \\
5.88\end{array}$ \\
\hline $\begin{array}{c}\text { II } \\
18 \text { months }\end{array}$ & $\begin{array}{r}\text { Mean } \\
\pm \text { SD }\end{array}$ & $\begin{array}{l}30.89^{\mathbf{b}^{*}} \\
14.78^{2}\end{array}$ & $\begin{array}{l}31.51 \\
11.03\end{array}$ & $\begin{array}{l}29.08 \\
9.62\end{array}$ & $\begin{array}{l}14.04^{\mathbf{a}^{* * *}} \\
7.51\end{array}$ \\
\hline $\begin{array}{c}\text { III } \\
24 \text { months }\end{array}$ & $\begin{array}{l}\text { Mean } \\
\pm \mathrm{SD}\end{array}$ & $\begin{array}{l}10.29^{\mathbf{b}^{* * * k}} \\
4.76\end{array}$ & $\begin{array}{l}29.41^{\mathbf{a}^{* * *}} \\
15.23\end{array}$ & $\begin{array}{l}31.04^{a^{* * k}} \\
9.78\end{array}$ & $\begin{array}{l}21.31^{\mathrm{a}^{* *}} \\
3.07\end{array}$ \\
\hline
\end{tabular}

1: control 2: swimming 3: diet restricted 4: vitamin E supplemented a: significance versus subgroup 1 of same age.

b: significance versus group I (12 month )(only for subgroup 1)

$*: \mathrm{p}<0.05 * *: \mathrm{p}<0.01 * * *: \mathrm{p}<0.001$

\section{DISCUSSION}

A major goal of researches in the field of aging has been the discovery of ways to reduce morbidity and delay mortality in the elderly, slowing aging and extending life expectancy ${ }^{(2)}$.

Serum MDA, which reflected the tissue lipid peroxidation level significantly increased in the adult group, while the activity of hepatic SOD enzyme as an antioxidant decreased with age. These observations indicate the presence of an age-dependent increase in oxidative stress manifested by both increased free radical production and decreased antioxidants. These results 
coincided with that observed by Huang et $\mathrm{al}^{(21)}$ and Navarro et al. ${ }^{(22)}$

In the present study, \% DNA fragmentation increased progressively with age together with increased active caspase- 3 concentrations in the brain of old rats. Increased DNA damage with aging was confirmed by several studies either in brain ${ }^{(23,24)}$ or in muscle. ${ }^{(25)}$ Age- dependent caspase3 activation was supported by previous results. ${ }^{(\mathbf{2 4 , 2 6})}$

DNA is a primary site of damage during oxidative stress, which is more extensive and persists longer in $\mathrm{mt}$ DNA than nuclear DNA. ${ }^{(27)}$ As free radical scavenger enzymes and DNA repair systems for removal of these oxidative damages become less efficient with aging. (28) This may account for the ever-increasing accumulation of oxidative damage $\mathrm{e}^{(29)}$ and/or mt-DNA mutations ${ }^{(\mathbf{3 0})}$ which promote apoptosis.

In spite of the increased DNA fragmentation of the brain, which was supposed to be a result of the increased brain oxidative stress, nonsignificant change in the activity of MAO- $\beta$ was detected. This result coincided with Tranquilli et $\mathrm{al}^{(\mathbf{3 1})}$ who suggested that MAO enzyme may be a region specific; increased in some regions and decreased in others. In contrast, Mantha et $\mathrm{al}^{(\mathbf{3 2})}$ reported an age-related decrease of brain MAO enzyme activity.

In the present study, hepatic NADPH cytochrome c reductase activity was significantly decreased with aging. Senescent- associated reduction in the activity and/or induction of different isoforms of hepatic monooxygenases were detected previously by several authors. ${ }^{(33,34)}$

Exercise training, by swimming through the schedule of the present experiment, could significantly attenuate the increased serum MDA without any effect on SOD activity in adult group. However, old trainee rats got the best benefit from exercise by both decreasing MDA levels and increasing SOD activity. The protective role of moderate exercise in the present study was confirmed in previous studies either through augmentation of SOD activity, ${ }^{(35)}$ decreasing $\mathrm{MDA}^{(36)}$ or just preventing the elevation of lipid peroxidation. ${ }^{(35,37)}$

$\%$ DNA fragmentation and active caspase- 3 brain levels in the current study showed different age-dependent responses to exercise. In young group's brain, both parameters were increased indicating stimulation of apoptosis which is a character of young aged cells by oxidative stress, ${ }^{(38)}$ while in adult rats, the exercise succeeded to prevent their increase. Old aged rats gained the best benefit from regular training as it not only prevented the increase in DNA fragmentation but also decreased caspase- 3 activation.

The protective effect of exercise against elevated apoptosis in the aged rats of the present study agreed with those from different studies in skeletal muscle $^{(39)}$ and brain. ${ }^{(40)}$ Wang et al ${ }^{(41)}$ suggested that moderate exercise attenuates apoptosis and DNA damage induced by oxidative stress possibly by decreasing lipid peroxidation and improving intracellular antioxidant capacity. Moreover, modulation of apoptotic supressors may be involved 
in training- induced attenuation of apoptosis. ${ }^{(42)}$

The present results deny an effect of exercise on MAO- $\beta$ activity as brain MAO- $\beta$ activity did not change significantly between trained and nontrained rats of the same age group. In contrast, Hattori et $\mathrm{al}^{(\mathbf{4 3})}$ reported decrease in its activity with exercise and suggested a relation between physical exercise and dopamine metabolism.

A significant improvement in the activity of the hepatic NADPH cytochrome c reductase activity in old aged trainee rats was detected in this study as compared to the sedentary rats of the same age. Day et $\mathrm{al}^{(\mathbf{4 4})}$ reported a similar effect on liver microsomal metabolism.

Caloric diet restriction (CR) by $30 \%$ in this study increased MDA level in young, decreased it in adults and had no effect on old rats. So, age is an important determinant for the beneficial effect of CR. While, CR had no effect on hepatic SOD activity whatever the age of the studied rats. In the adult group, CR could ameliorate oxidative stress by decreasing oxidants as MDA rather than increasing antioxidants as SOD. These findings agreed with that of some authors. $^{(45)}$

Reducing caloric intake may reduce oxygen consumption, which could decrease ROS formation and oxidative stress. ${ }^{(\mathbf{4 6})}$ Ad libitum and CR animals differ in mitochondrial activity and glycolytic flow rates. Persistent glycolysis in un-restricted condition would increase glycolytic intermediates which can glycate proteins thus damages mitochondria and induces pro-oxidant state. ${ }^{(4)}$
The dietary restricted young rats involved in this study had higher \% DNA fragmentation than that found in the ad libitum of the same age. This could be partially explained by the presence of associated high lipid peroxidation state and high metabolic rate of the young. Of a major interest is the fact that the amount of DNA damage correlates with the metabolic rate in various animals. ${ }^{(46)}$

However, the reverse occurred with old CR rats, which showed lower $\%$ DNA fragmentation than those without restriction. Wolf et al (48) stated that $40 \% \quad \mathrm{CR}$ effectively reduced age- dependent increase of oxidative DNA damage in all tissues particularly brain of 24 month old rats as compared to 4 month old ones. It has been suggested that $\mathrm{CR}$ may provide neuroprotection to the aging brain by preserving DNA repair enzymes in their intact form. In addition, this involves a preconditioning response in which the production of neurotrophic factors and protein chaperones is increased resulting in protection against oxyradical production, stabilization of cellular calcium homeostasis, and inhibition of apoptosis. ${ }^{(49)}$

The present data did not prove any effect of $\mathrm{CR}$ on brain active caspase-3 levels in all the studied age groups. Shelke \& Leeuwenburgh (50) confirmed this result and stated that CR increases expression of apoptosis suppressor with a caspase recruitment domain in the brain.

Brain MAO- $\beta$ activity was found to be insignificantly changed with $\mathrm{CR}$. The beneficial effects of CR depends on many factors as the severity of the restriction, the specific animal species, 
age at onset of restriction, and the grade of restriction. ${ }^{(51)}$

$\mathrm{CR}$ caused a significant improvement in hepatic NADPH cytochrome c reductase activity in old aged rats. Diet restriction can decrease the rate of metabolism and increase the ability of the animal to face toxins by enhancing the activity of the drugmetabolizing enzyme of the major organ of detoxification. ${ }^{(\mathbf{5 2})}$

The present study demonstrated that supplementation of vitamin $\mathrm{E}$ in adult and old groups could significantly reduce MDA as compared with that of the nonsupplemented animals of the same age group. This finding was in agreement with a previous report. ${ }^{(53)}$

However, vitamin E supplementation caused a significant decrease in SOD activity of young and old rats when compared with their cohorts. It appears that vitamin E could stand out as a significant tool in ameliorating the oxidative stress when started in adulthood or even in old age. Vitamin E could be beneficial to decrease oxidant production rather than activating endogenous antioxidants as SOD. Huang et al ${ }^{(\mathbf{5 4})}$ found that long term in vitro incubation of rat aortic muscle with vitamin $\mathrm{E}$ down regulated SOD activity.

Vitamin E supplementation to young rats had no effect on \% DNA fragmentation or caspase- 3 activation, while in old rats vitamin $\mathrm{E}$ decreased $\%$ DNA fragmentation and increased active caspase-3 levels when compared with their corresponding age groups. Possible consequences of DNA damage are repair, apoptosis/necrosis or defective repair. ${ }^{(29,30)}$ So, it is supposed that endogenous and nutritional antioxidant system have to be adjusted to ensure adequate removal of radicals during stress to prevent ROS- induced damage. Because of the associated age- related decline of vitamin $\mathrm{E},{ }^{\mathbf{( 5 5})}$ it could act efficiently in old rats to decrease DNA damage and increase apoptosis. Vitamin E could not prevent stress- induced apoptosis either in fibroblasts, ${ }^{\mathbf{( 5 6}}$ or neurons. ${ }^{(57)}$

Oral Vitamin E supplementation to rats of different ages could not cause a significant change in brain MAO- $\beta$ activity. As reported previously vitamin $\mathrm{E}$ failed to inhibit MAO- $\beta$ activity in the nigrostriatal dopaminergic neurons in rats. ${ }^{(58)}$

Vitamin E supplementation appeared to have controversial effects on NADPH cytochrome c reductase activity depending on the age group. However, its activity was adjusted by vitamin $\mathrm{E}$ to be nearly similar in all groups of the study whatever the age.

Vitamin E was detected to be depleted from various tissues with aging, and when supplemented its concentration would be elevated. ${ }^{(59)}$ The restored vitamin E could explain the increased activity of NADPH cytochrome c reductase selectively in old aged rats at the present study.

Vitamin E could improve hepatic drug metabolism partially by decreasing oxidants ${ }^{(60)}$ and by inducing and activating liver microsomal cytochrome enzymes ${ }^{(61)}$ It has now become clear that vitamin $\mathrm{E}$ has functions far exceeding that as an antioxidant. Vitamin $\mathrm{E}$ is able to directly influence gene activity. ${ }^{(62)}$

These data demonstrated an agedependent increase in oxidative stress, 
DNA damage, apoptosis and improper ability of the liver to deal with toxins. Exercise could decrease oxidants, increase antioxidants, resist brain apoptosis and improve liver metabolism. Dietary restriction and vitamin E supplementation could act primarily by decreasing oxidants and DNA damage as well as increasing cytochrome c reductase liver enzyme. So, it is suggested that the ageinduced damage could be partially attenuated by exercise training, dietary restriction or vitamin $\mathrm{E}$ supplementation. All these beneficial effects might be mostly effective in the older age.

\section{REFERENCES}

1. Kanapowski J, WieczorowskaTobis K, Witowski J (2002). Pathophysiology of aging. J Physiol Pharmacol; 53 (2): 135 46.

2. Bruce R, Troen M D (2003). The biology of aging. The Mount Sinai J Med; 70 (1): 3-21.

3. Weinert $B$ T, Timiras $\mathbf{P} S$ (2003). Invited Review: Theories of aging. J Appl Physiol; 95: $1706-16$.

4. Wei Y H, Lee H C (2002). Oxidative stress, mitochondrial DNA mutation, and impairment of antioxidant enzymes in aging. Exp Biol Med; 227: $671-82$.

5. Sastre J, Pallardo F V, Vina J (2000). Mitochondrial oxidative stress plays a key role in aging and apoptosis.IUBMB Life; 49 (5): 427- 35 .

6. Reneham A G, Booth C, Potten C S (2001). What is apoptosis, and why is it important? B M J; 322:1536-8.

7. Gallaher B W, Hille R, Raile K, Kiess W (2001). Apoptosis: live or die-hard work either way! Horm Metab Res; 33: 511 - 518.

8. Kumar M J, Andersen $\mathbf{J} \mathbf{K}$ (2004). Perspectives on MAO-B in aging and neurological disease: where do we go from here? Mol Neurobiol; 30 (1): 77 - 89.

9. Leon A S, Horst W D, Spirt N, Wiggan E B, Omelsdorf A $\mathbf{H}$ (1975). Heart norepinephrine levels after exercise training in the rats. Chest; 67: 341-3.

10. Risby $T$ H, Jiang L, Stoll $S$, Ingram D, Spangler E, Heim J, Cutler R, Roth G R, Rifkind J $M$ (1999). Breath ethane as a marker of reactive oxygen species during manipulation of diet and oxygen tension in rats. J Appl Physiol; 86(2): $617-22$.

11. Reckelhoff J F, Kanji V, Racusen L C, Schmidt A M, Yan S D, Morrow J, Roberts L J II, Salahudeen A K (1998). Vitamin E ameliorates enhanced renal lipid peroxidation and accumulation of $\mathrm{F}_{2}$-isoprostanes in aging kidneys. Am J Physiol; 274(Regulatory Integrative Comp Physiol): R $767-74$.

12. Du Y, Bales KR, Dodel RC, Hamiton-Byrd E, Horns JW, Czilli DL, Simmons LK, Ni B, Paul SM (1997). Activation of caspase-3 related cysteine protease is required for glutamate-mediated apoptosis of cultured cerebellar granule neurons . Proc Natl Acad Sci USA; 94: 11657-62. 
13. Ohkawa H, Ohishini N, Yagi K (1979). Assay for lipid peroxides in animal tissues by thiobarbituric acid reaction. Anal Biochem; 95: $351-8$.

14. Burton K (1956). A study of the conditions and mechanism of the diphenylamine reaction for the colorimetric estimation of deoxyribonucleic acid. Biochem J; 62: 315-22.

15. Sellins K S, Cohen J J (1987). Gene induction by $\gamma$-irradiation leads to DNA fragmentation in lymphocytes. J Immunol; 139: 3199 - 206.

16. Talanian $\mathbf{R} \mathrm{V}$, Quinlan $\mathrm{C}$, Trautz S, Hackett M C, Mankovich J, Banach D, Ghayur T (1997). Substrate specificities of caspase family proteases, J Biol Chem; 272(15): $9677-82$.

17. Lowry O H, Rosebrough $\mathbf{N}$ J, Farr A L, Randall RJ (1951). Protein measurement with the folin phenol reagent. J Biol Chem; 193: 265 - 75.

18. Berridge M V, Tan A S (1993). Characterization of the cellular reduction of $3-(4,5$ dimethylthiazol 2-yl)-2,5 diphenyl tetrazolium bromide (MTT): subcellular localization, substrate dependence, and involvement of mitochondrial electron transport in MTT reduction. Arch Biochem Biophys; 303: 474 - 82.

19. Marklund S, Marklund G (1974). Involvement of the superoxide anion for superoxide dismutase. Eur J Biochem; 47: 469 - 74.
20. Williams CH, Kamin H (1952). Microsomal triphosphopyridine nucleotide- cytochrome c reductase of liver. J Biol Chem; 237: 587-95.

21. Huang SZ, Luo YJ, Wang L, Cai KY (2005). Effect of Ginko biloba extract on livers in aged rats. World $\mathrm{J}$ Gastroenterol; 11(1): 132-5.

22. Navarro A, Boveris A (2004). Rat brain and liver mitochondria develop oxidative stress and lose enzymatic activities on aging. Am J Physiol (Regul Integr Comp Physiol); 287 (5): R 1244 - 9.

23. Kim $G$ W, Chan $P$ H (2001). Oxidative stress and neuronal DNA fragmentation mediate agedependent vulnerability to the mitochondrial toxin, 3nitropropionic acid, in the mouse striatum. Neurobiol Dis; 8 (1): $114-26$.

24. Lesuisse C, Martin L J (2002). Long-term culture of mouse cortical neurons as a model for neuronal development, aging, and death. J Neurobiol; 51 (1): 9- 23.

25. Chung L, Ng YC (2006). Agerelated alterations in expression of apoptosis regulatory proteins and heat shock proteins in rat skeletal muscle. Biochim Biophys Acta; 1762(1): 103-9.

26. Brewer GJ, Lim A, Capps NG, Torricelli JR (2005). Age related calcium changes, oxyradical damage, caspase activation and nuclear condensation in hippocampal neurons in response to glutamate and beta-amyloid. Exp Gerontol; 40(5): 426-37.

27. Yakes FM, Van Houten B (1997). Mitochondrial DNA 
damage is more extensive and persists longer than nuclear DNA damage in human cells following oxidative stress. Proc Natl Acad Sci; 94: $514-9$.

28. Davydov V V, Dobaeva N M, Bozhkov A I (2004). Possible role of alteration of aldehyde's scavenger enzymes during aging. Exp Gerontol; 39 (1): $11-6$.

29. Ledoux $S \quad P$, Driggers $W \quad J$, Hollensworth B S, Wilson G L (1999). Repair of alkylination and oxidative damage in mitochondrial DNA. Mutat Res; 434: 149 - 59.

30. Trifunovic A, Hansson A, Wredenberg A, Rovio AT, Dufour E, Khvorostov I, Spelbrink JN, Wibom R, Jacobs HT, larsson NG (2005). Somatic mtDNA mutations cause aging phenotypes without affecting reactive oxygen species production. Proc Natl Acad Sci USA; 102(50): 17993-8.

31. Tranquilli $F$ M, Artico $M$, Potenza S, Cavallotti C (2003). Age-related changes of monoamine oxidases in rat cerebellar cortex. Eur J Histochem; 47 (1): 81- 6.

32. Mantha AK, Moorthy $K$, Cowsik SM, Baguer NZ (2006). Neuroprotective role of neurokinin B (NKB) on betaamyloid (25-35) induced toxicity in aging rat brain synaptosomes: involvement in oxidative stress and excitotoxicity. Biogerontology; 7(1): 1-17.

33. Warrington J S, Greenblatt $D$ J, von Moltke L L (2004). Agerelated differences in CYP3A expression and activity in the rat liver, intestine, and kidney. $\mathrm{J}$ Pharmacol Exp Ther; 309: 720 -9.

34. Agrawal AK, Shapiro BH (2003). Constitutive and inducible hepatic cytochrome P450 isoforms in senescent male and female rats and response to low-dose phenobarbital. Drug Metab Dispos; 31(5): 612-9.

35. Gunduz F, Senturk UK, Kuru O, Aktekin B, Aktekin MR (2004). The effect of one year's swimming exercise on oxidant stress and antioxidant capacity in aged rats. Physiol Res; 53(2): 171-6.

36. Kim HT (2005). Effect of the joint administration of selenium and vitamin $\mathrm{E}$ in combination with regular aerobic exercise on markers of lipid peroxidation and glutathione peroxidase in diabetic rats. Int J sport Nutr Exerc Metab; 15(3): 266-78.

37. Navarro A, Gomez C, LopezCepero J M, Boveris A (2004). Beneficial effects of moderate exercise on mice aging: survival, behavior, oxidative stress and mitochodrial electron transfer. Am J Physiol (Regul Integr Comp Physiol); 286 (3): R 505 - 11.

38. Quadrilatero J, Hoffman-Goetz L (2005). N-acetyl-L-cysteine inhibits exercise-induced lymphocyte apoptotic protein alterations. Med Sci Sports Exerc; 37(1): 53-6.

39. Song W, Kwak HB, Lawler JM (2006). Exercise training attenuates age-induced changes in apoptotic signaling in rat skeletal muscle. Antioxid Redox Signal; 8(3-4): 517-28. 
40. Sim YJ, Kim H, Kim JY, Yoon SJ, Kim SS, Chang HK, Lee TH, Lee HH, Shin MC, Shin MS, Kim CJ (2005). Long-term treadmill exercise overcomes ischemia-induced apoptotic neuronal cell death in gerbils. Physiol Behav; 84(5): 733-8.

41. Wang JS, Huang YH (2005). Effects of exercise intensity on lymphocyte apoptosis induced by oxidative stress in men. Eur $\mathrm{J}$ Appl Physiol; 95(4): 290-7.

42. Siu PM, Bryner RW, Murlasits Z, Alway SE (2005). Response of XIAP, ARC, and FLIP apoptotic suppressors to $8 \mathrm{wk}$ of treadmill running in rat heart and skeletal muscle. J Appl Physiol; 99(1): 204-9.

43. Hattori S, Naoi $M$, Nishino $H$ (1994). Striatal dopamine turnover during treadmill running in the rat: relation to the speed of running. Brain Res Bull; 35: 41 9.

44. Day W W, Chesky J A, Weiner $M$ (1992). Differential effects of swimming and running on microsomal metabolism in middle-aged and aged Fischer 344 rats. Mech Ageing Dev; 63 (3): $275-86$.

45. Wu A, Sun $X$, Wan F, Liu Y (2003). Modulations by dietary restriction on antioxidant enzymes and lipid peroxidation in developing mice. J Appl Physiol; 94 (3): 947 - 52.

46. Heilbronn $L$ K, Ravussin $E$ (2003). Calorie restriction and aging: review of the literature and implications for studies in humans. Am J Clin Nutr; 78 (3): $361-9$.
47. HipKiss AR (2006). Does chronic glycolysis accelerate aging? Could this explain how dietary restriction works? Ann N Y Acad Sci; 1067: 361-8.

48. Wolf FI, Fasanella S, Tedesco B, Cavallini G, Donati A, Bergamini E, Cittadini A (2005). Peripheral lymphocyte 8OHdG levels correlate with ageassociated increase of tissue oxidative DNA damage in Sprague-Dawley rats. Protective effects of caloric restriction. Exp Gerontol; 40(3):181-8.

49. Prolla $T$ A, Mattson $M \quad P$ (2001). Molecular mechanisms of brain aging and neurodegenerative disorders: lessons from dietary restriction. Trends Neurosci; 24 (11 Suppl): $21-31$.

50. Shelke $R$ R, Leeuwenburgh $\mathbf{C}$ (2003). Lifelong caloric restriction increases expression of apoptosis repressor with a caspase recruitment domain (ARC) in the brain. FASEB J; 17 (3): $494-6$.

51. Merry B J (2002). Molecular mechanisms linking caloric restriction and longevity. Int $\mathrm{J}$ Biochem Cell Biol; 34: 1340 - 54.

52. Schmucker D L, Wang $R$ K, Snyder D, Strobel H, Marti U (1991). Caloric restriction affects liver microsomal monooxygenases differentially in aging male rats. J Gerontol; 46: B $23-7$.

53. Koyu A, Ozguner F, Caliskan S, Karaca H (2005). Preventive effect of vitamin $\mathrm{E}$ on ironinduced oxidative damage in 
rabbit. Toxicol Ind Health; 21(9): 239-42.

54. Huang W, Chan $P$, Chen $Y$, Chen C, Liao S, Chin W, Cheng J (1999). Changes of superoxide dismutase in cultured rat aortic smooth muscle cells (A7r5) by an incubation of vitamin $\mathrm{E}$. Pharmacology; 59 (5): 275 - 82.

55. Sumien N, Heinrich $K R$, Sohal R S, Forster M J (2004). Shortterm vitamin $\mathrm{E}$ intake fails to improve cognitive or psychomotor performance of aged mice. Free Radic Biol Med; 36 (11): 1424 - 33.

56. Nunes VA, Gozzo AJ, CruzSilva I, Juliano MA, Viel TA, Godinho RO, Meirelles FV, Sampaio MU, sampaio CA, Araujo MS (2005). Vitamin E prevents cell death induced by mild oxidative stress in chicken skeletal muscle cells. Comp Biochem Physiol C Toxicol Pharmacol; 141(3): 225-40.

57. De Ruvo C, Amodio $R$, Algeri S, Martelli N, Intilangelo $\mathrm{A}$, D'Ancona $G \mathbf{M}$, Esposito $\mathbf{E}$ (2000). Nutritional antioxidants as anti-degenerative agents. Int $\mathrm{J}$ Dev Neurosci; 18 (4-5): 359 - 66.
58. Miklya I, knoll B, Knoll J (2003). A pharmacological analysis elucidating why, in contrast to (-)-deprenyl (selegiline), alpha-tocopherol was ineffective in the DATATOP study. Life Sci; 72(23): 2641-8.

59. Huang H Y, Appel L J, Croft K D, Miller $\mathbf{E} \mathbf{R} 3^{\text {rd }}$, Mori $\mathbf{T} A$, Puddey I B (2002). Effects of vitamin $\mathrm{C}$ and vitamin $\mathrm{E}$ on in vivo lipid peroxidation: results of a randomized controlled trial. Am J Clin Nutr; 76 (3): 549 - 55.

60. Kim JY, Lee SM (2006). Vitamins $\mathrm{C}$ and $\mathrm{E}$ protect hepatic cytochrome P450 dysfunction induced by polymicrobial sepsis. Eur J Pharmacol; 534(1-3): 2029.

61. Sidorova YA, Grishanova AY, Lyakhovich VV (2004). Transcriptional activation of cytochrome P4501A1 with alphatocopherol. Bull Exp Biol Med; 138(3): 233-6.

62. Brigelius- Folche $R$ (2005). Induction of drug metabolizing enzymes by vitamin E. J Plant Physiol; 162(7): 797-802. 
تأثير التمارين الرياضية وتحديد سعرات الغذاء والأمداد بمضادات الأكسدة على عملية الشيخوخة عند الفئران

$$
\begin{aligned}
& \text { صبحى الكفافى ، سامى حمادى" ، عمرو النوبعم ، أبيان محد فوزى ، }
\end{aligned}
$$

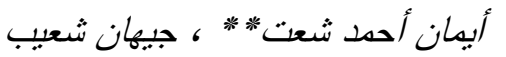

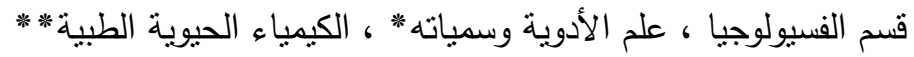

$$
\begin{aligned}
& \text { كلية الطب ، جامعة الإسكندرية }
\end{aligned}
$$

الغرض من هذا البحث هو تقييم تأثنير كلا من السن ،والتمارين الرياضية ،وتحديد

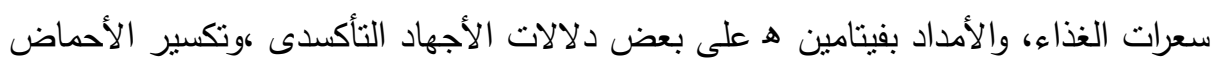
النووية ،والموت المبرمج للخلايا ووظيفة الكبد فى المجموعات العمرية المختلفة للفئران.

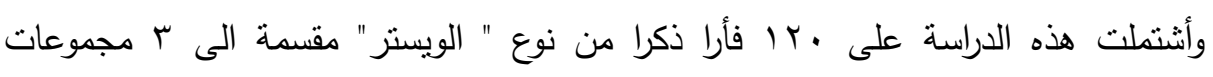

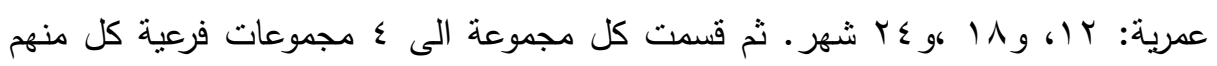

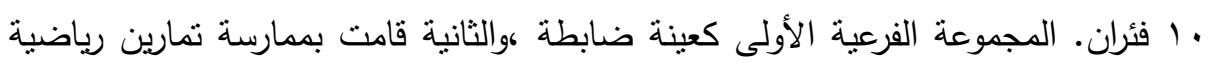
،والثالثة خفضت لها سعرات الغذاء والأخيرة نم أمدادها بفيتامين هـ وأنشتملت التئلة القياسات

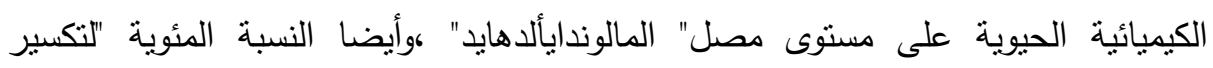

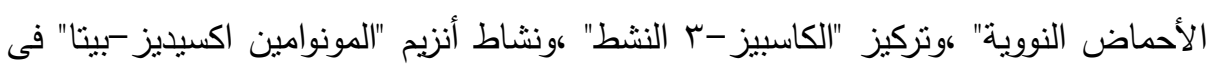

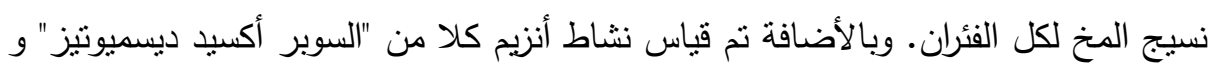

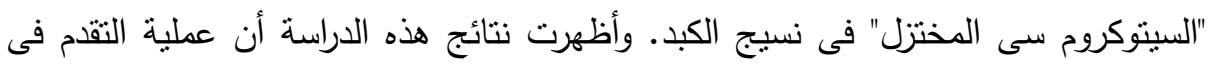

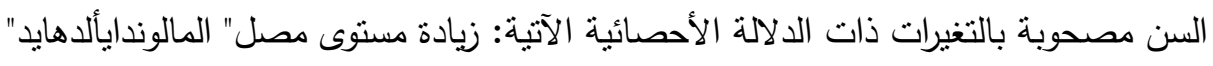

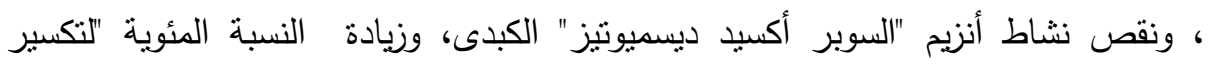

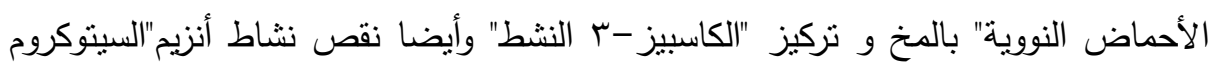

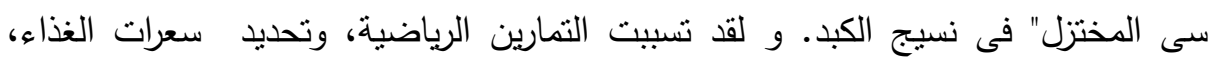

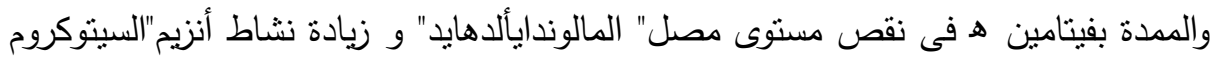
سى المختزل" الكبدى تغيرا ذو دلالة أحصائية فى مجموعة الفئران ذات العمر الكبير.

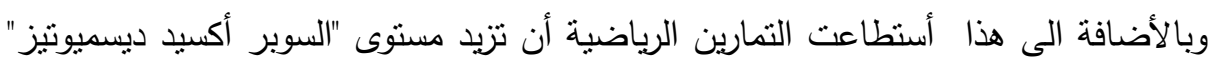


وتتقص تركيز "الكاسبيز -r النشط" ذوى أهية أحصائية فى مجموعة الفئران ذات العمر

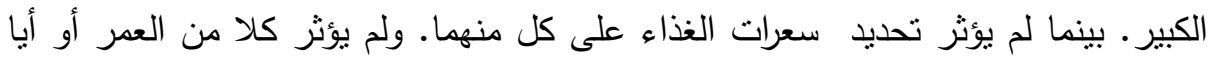

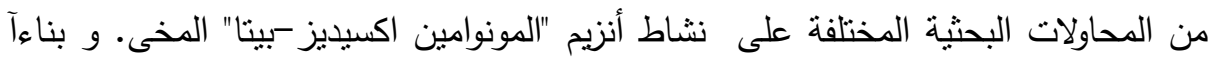
على هذا يقترح أن التغيرات المصاحبة للشيخوخة كالأجهاد التأكسى ،وتكسير التهائ الأحماض

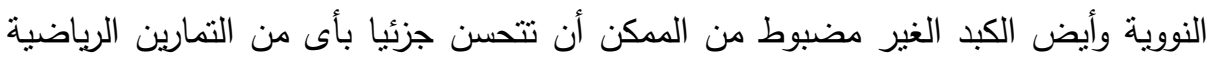

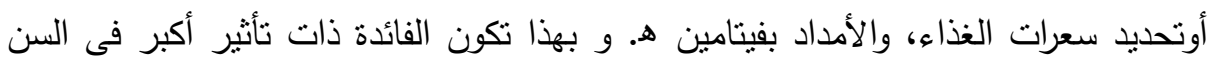
الكبير الكن 